\title{
Long-term effects of ad libitum whole milk prior to weaning and prepubertal protein supplementation on skeletal growth rate and first-lactation milk production
}

\author{
U. Moallem, ${ }^{* 1}$ D. Werner, $\dagger$ H. Lehrer, ${ }^{*}$ M. Zachut, ${ }^{*}$ L. Livshitz, ${ }^{*}$ S. Yakoby, ${ }^{*}$ and A. Shamay* \\ *Department of Dairy Cattle, Institute of Animal Sciences, Volcani Center, PO Box 6, Bet-Dagan, 50250 Israel \\ †Department of Cattle Husbandry, Extension Service, Ministry of Agriculture, PO Box 28, Bet-Dagan, 50250, Israel
}

\begin{abstract}
Our objectives were to determine the effects of rapid growth rate during the preweaning period and prepubertal protein supplementation on long-term growth pattern and milk production during the first lactation. Forty-six Israeli Holstein heifer calves were fed either milk replacer (MR) or whole milk (WM) from 4 to $60 \mathrm{~d}$ age. Calves had free access to WM or MR for 30 min twice daily and free-choice water and starter mix for the entire day. From weaning until $150 \mathrm{~d}$ of age, all heifers were fed the same ration. At $150 \mathrm{~d}$ of age the heifers were divided into 2 subgroups, with one subgroup supplemented with an additional $2 \%$ protein until $320 \mathrm{~d}$ of age. Thereafter, all heifers were housed and fed together until calving. Another cluster of 20 heifers was raised on MR and WM treatments and 3 animals from each nursery treatment were slaughtered at $60 \mathrm{~d}$ and $10 \mathrm{mo}$ age to determine effects of nursery treatment on organ and adipose tissue mass. Prior to weaning, the MR heifers consumed $0.12 \mathrm{~kg} / \mathrm{d}$ more DM than the WM heifers, but metabolizable energy intake was not different. Body weight at weaning and average daily gain during the preweaning period were $3.1 \mathrm{~kg}$ and $0.074 \mathrm{~kg} / \mathrm{d}$ higher, respectively, in the WM treatment than in the MR treatment, with no differences in other measurements. Nursery feeding treatment and added protein had no effect on growth rate in the prepubertal period, but the postweaning difference in BW between the WM and MR heifers remained throughout the entire rearing period. The age at first insemination was $23 \mathrm{~d}$ earlier and age at pregnancy and first calving was numerically lower for the WM heifers than for the MR heifers. Adipose tissue weights at weaning were doubled in the WM calves. First-lactation milk production and $4 \%$ fat-corrected milk were 10.3 and $7.1 \%$ higher, respectively, for WM heifers than for MR heifers, whereas prepubertal added protein tended to
\end{abstract}

Received December 17, 2009.

Accepted February 12, 2010.

${ }^{1}$ Corresponding author: uzim@volcani.agri.gov.il increase milk yield. In conclusion, preweaning WM at high feeding rates appears to have long-term effects that are beneficial to future milk production. The positive long-term effects of feeding WM on first-lactation milk production were independent of their effects on skeletal growth. Enhanced milk production observed with WM treatment may be related to the milk supply, paracrine or endocrine effects of fat tissues on mammary parenchyma, or a combination of both factors.

Key words: whole milk nursery, fat tissue, milk production

\section{INTRODUCTION}

In a meta-analysis, Zanton and Heinrichs (2005) assessed the effects of prepubertal growth rate and BW at calving on first-lactation milk production. They found that milk yield was associated quadratically with ADG, and maximal production was achieved with a prepubertal ADG of $799 \mathrm{~g} / \mathrm{d}$. They also found a tendency for increased milk production with increased BW at calving. A positive relationship between $\mathrm{BW}$ at first calving and milk yield was also shown by Hoffman and Funk (1992). Radcliff et al. (2000) reported higher milk production in heifers that gained $0.770 \mathrm{~kg} / \mathrm{d}$ during the prepuberty period as compared with $1.12 \mathrm{~kg} / \mathrm{d}$, which is in accordance with the findings of Zanton and Heinrichs (2005).

The period from birth to 3 mo of age is the first developmental stage of the mammary gland, during which mammary growth rate is similar to that of other organs (the first isometric phase). Conversely, from $3 \mathrm{mo}$ of age until completion of several estrus cycles, relative growth rates of mammary gland are more than 3-fold greater than for BW. This period was defined as the allometric phase of mammary development (Sinha and Tucker, 1969; Swanson and Poffenbarger, 1977). Most research (Sejrsen et al., 1998) on the effects of body and mammary gland growth rates on milk production was conducted during the allometric growth phase, a period during which mammary ductile tissue is developing within the mammary fat pad. Rapid growth 
during this phase has been shown to be detrimental to mammary development, potentially reducing future milk yield (Sejrsen et al., 1982; Foldager and Sejrsen, 1991; Capuco et al., 1995). However, Silva et al. (2002) reported that accelerated prepubertal growth rates did not impair mammary development as measured by parenchymal tissue deposition.

In a previous study conducted in our laboratory (Shamay et al., 2005), heifer calves fed ad libitum whole milk (WM) had accelerated growth rates compared with those fed restricted milk replacer (MR), and when the WM heifers were supplemented with $2 \%$ protein during the prepuberty period, their milk production during the first lactation was enhanced as compared with calves fed MR in standard regimen. Similarly, heifer calves that were allowed to suckle the same dam 3 times daily during the first $42 \mathrm{~d}$ of age had higher $\mathrm{BW}$ at weaning and withers height ( $\mathbf{W H}$ ) at calving and tended to produce more milk during the first lactation (Bar-Peled et al., 1997). These studies suggest beneficial effects of increased growth rate during the nursery period without negative effects on first-lactation milk yield. Sejrsen et al. (1998) also conclude that rapid growth rate until 4 mo of age did not negatively affect mammary development. Because mammary gland development from birth until 3 mo of age is relatively small, it might be that the negative effect of accelerated growth on mammary gland development is pertinent only during the prepubertal period.

The objective of the present study was to examine the long-term effects of ad libitum feeding of WM or MR during the preweaning period and $2 \%$ added protein during the subsequent prepubertal period on growth rates and milk production during the first lactation.

\section{MATERIALS AND METHODS}

\section{Animals and Treatments}

The experimental protocol and procedures were approved by the Volcani Center Animal Care Committee. Forty-six Israeli Holstein heifer calves at the experimental dairy farm of the Volcani Center (Bet Dagan, Israel) were raised in individual calf hutches until $90 \mathrm{~d}$ of age. All calves were fed colostrum for $3 \mathrm{~d}$ after birth and thereafter were allotted randomly to one of 2 experimental groups. Heifers were fed ad libitum twice daily for $30 \mathrm{~min}$ at $0700 \mathrm{~h}$ and $1500 \mathrm{~h}$ either a commercial MR or fresh WM. Representative samples of milk were taken 3 times weekly to determine fat, protein, and lactose by infrared analysis (standard IDF 141C; International Dairy Federation, 2000) at the laboratories of the Israeli Cattle Breeders Association (Caesarea, Israel). The MR was diluted according to the WM solids content (DM basis) such that both groups were offered equal MR or WM with solids concentrations. The average DM content of WM was $12.2 \%$, which contained $29.4 \%$ fat, $25.9 \%$ protein, and $40.7 \%$ lactose, with a $4 \%$ residual (ash). The MR contained $23.7 \% \mathrm{CP}$ (92\% milk protein sources) containing $14 \%$ casein, $13 \%$ fat, and $8 \%$ ash. The ME concentration of $\mathrm{WM}$ and MR was calculated according to NRC (2001). Water and starter mix (Table 1) were offered ad libitum until weaning at $60 \mathrm{~d}$ of age. To reduce weaning stress, WM and MR were gradually reduced at $50 \mathrm{~d}$ of age. Amounts of WM and MR offered to heifers were reduced $30 \%$ from 51 to 53 d, reduced another $30 \%$ from 54 to 56 d, and reduced $30 \%$ from 57 to $60 \mathrm{~d}$ of age. At weaning, calves in both groups were fed a starter mix and remained in individual hutches until $90 \mathrm{~d}$ of age. From 90 and $140 \mathrm{~d}$ of age, the heifers were group housed and fed a lactating cow ration that contained $16.5 \% \mathrm{CP}$ and $1.75 \mathrm{Mcal}$ of $\mathrm{NE}_{\mathrm{L}}$ (Table 1). From 140 to $150 \mathrm{~d}$ of age, the heifers were gradually adjusted to growing heifer ration (Table 1), and at $150 \mathrm{~d}$ of age, the heifers of each original group were divided into 2 treatment subgroups according to $\mathrm{BW}$ and WH measurements. Both groups were housed in one side of an open barn and each treatment group was divided into 2 pens, each holding 11 to 12 heifers. One of each subgroup of heifers was fed the growing heifer ration and the other group was supplemented with an additional $2 \%$ protein (Table 1), creating 4 subgroups as follows: MR + control (MRC), MR + $2 \%$ added protein (MRP), WM + control (WMC), and $\mathrm{WM}+2 \%$ added protein (WMP). From $320 \mathrm{~d}$ of age until calving, the heifers were raised together in 1 group and fed the growing heifer diet. During the last 4 wk of pregnancy, heifers were supplemented with 4 $\mathrm{kg}$ of DM of lactating cow diet, and after calving the heifers were housed and fed the same lactating cow diet as a single group (Table 1).

To determine the effects of nursery treatments on growth rates of the digestive tract, visceral organs, and fat deposition, nursery treatments were randomly applied to a second cluster of 20 heifers. From 90 and 140 $\mathrm{d}$ of age, the heifers were fed a lactating cow ration, and from $150 \mathrm{~d}$ until $320 \mathrm{~d}$ of age they were fed the same growing heifer ration (Table 1) except that no protein treatment was applied.

\section{Slaughter Measurements}

At $60 \mathrm{~d}$ of age, 6 heifers ( 3 from each nursery treatment group), selected to be comparable in BW to heifers in the growth study, were anesthetized with 1 $\mathrm{mL} / 1.5 \mathrm{~kg}$ of BW of pentobarbitone $(200 \mathrm{mg} / \mathrm{mL}$; CTS Chemical industries Ltd., Kiryat Malaachi, Israel) and transported to the adjacent abattoir of the Kimron 
Table 1. Ingredients and chemical composition of the starter mix, growing heifer, and lactating cow diets

\begin{tabular}{|c|c|c|c|c|}
\hline \multirow[b]{2}{*}{ Item } & \multirow[b]{2}{*}{ Starter mix } & \multicolumn{2}{|c|}{ Growing heifer } & \multirow[b]{2}{*}{ Lactating cow } \\
\hline & & Control & $2 \%$ protein & \\
\hline \multicolumn{5}{|l|}{ Ingredient, $\%$ of DM } \\
\hline Corn grain & 28.2 & 1.8 & 1.5 & 16.9 \\
\hline Barley grain & 29.5 & - & - & 6.3 \\
\hline Wheat grain & - & - & - & 8.1 \\
\hline Wheat bran & - & 9.8 & 7.8 & - \\
\hline Soybean meal & 12.8 & - & 3.0 & 6.4 \\
\hline Rapeseed meal & - & - & - & 1.4 \\
\hline Sunflower meal & - & 6.5 & 5.2 & 4.8 \\
\hline Gluten feed & - & 17.1 & 13.5 & 6.4 \\
\hline Gluten meal & - & - & 4.6 & - \\
\hline Cotton seeds & 2.0 & - & - & 4.5 \\
\hline Soybean hulls & - & - & - & 1.4 \\
\hline Dried distillers grain & - & - & - & 4.7 \\
\hline Soy molasses & - & - & - & 1.7 \\
\hline Sunflower seed hulls & - & 5.7 & 4.5 & - \\
\hline Oat hay & - & - & - & 6.0 \\
\hline Wheat straw & - & 32.4 & 38.2 & - \\
\hline Vetch hay & 15.9 & - & - & 3.5 \\
\hline Wheat hay & - & 11.2 & 9.0 & - \\
\hline Wheat silage & - & - & - & 8.0 \\
\hline Cotton gin waste & - & 11.7 & 9.3 & 17.8 \\
\hline Foxtail grass & - & 3.7 & 3.0 & - \\
\hline Vegetable oil & 0.4 & - & - & - \\
\hline Protected fat & - & - & - & 0.2 \\
\hline Limestone & - & - & - & 1.5 \\
\hline Vitamin and mineral $^{1}$ & 0.1 & 0.1 & 0.1 & 0.1 \\
\hline Rumensin $^{2}$ & 0.1 & - & - & - \\
\hline \multicolumn{5}{|l|}{ Chemical composition } \\
\hline $\mathrm{CP}, \%$ of DM & 18.1 & 13.2 & 15.2 & 16.5 \\
\hline $\mathrm{NDF}, \%$ of DM & 24.0 & 55.9 & 53.0 & 32.0 \\
\hline $\mathrm{NE}_{\mathrm{L}}, \mathrm{Mcal} / \mathrm{kg}$ of DM & - & - & - & 1.75 \\
\hline $\mathrm{ME}, \mathrm{Mcal} / \mathrm{kg}$ of DM & 3.16 & 2.89 & 2.91 & - \\
\hline
\end{tabular}

${ }^{1}$ In starter mix diet, contained per $\mathrm{kg}$ of mix: vitamin A, 12,800,000 IU; vitamin D, 2,560,000 IU; vitamin E, 16,000 mg; Mn, 64.0 g; Zn, 64.0 g; Fe, 64.0 g; Cu, 32.0 g; I, 12.8 g; Se, 0.32 g; Co, 0.48 g. In lactating cow diet, contained per $\mathrm{kg}$ of mix: vitamin A, 20,000,000 IU; vitamin D, 2,000,000 IU; vitamin E, 15,000 mg; Mn, 6.0 g; $\mathrm{Zn}, 6.0 \mathrm{~g}$; Fe, $2.0 \mathrm{~g}$; Cu, 0.5 g; I, $0.12 \mathrm{~g}$; Se, 0.05 g; Co, 0.02 g.

${ }^{2}$ Elanco (Greenfield, IN).

Veterinary Institute (Bet Dagan, Israel). Visceral organs, including heart, liver, kidney, spleen, and lungs, were separated and weighed. The digestive tract segments with digesta contents were separated (rumen and reticulum, omasum and abomasum, small intestine and large intestine), isolated, and weighed. Subsequently, the digestive tract tissue segments were emptied, washed with cool water, drained, and weighed empty. Gut fill within intestinal tract was determined as the difference between full and empty weights of digestive tract segments. The omental tissue was separated and weighed and the mesentery fat was dissected and also weighed. The groin fat was separated from both sides and weighed. Mammary gland and the fat surrounding the gland was removed and weighed. At the laboratory, the mammary fat pad was isolated from parenchyma and weighed.

At 10 mo of age, an additional 6 heifers (3 from each nursery group), selected to be comparable in BW to heifers in the growth study, were slaughtered at a commercial abattoir. Kidney and mammary gland and fat surrounding them were removed; thereafter, the fat surrounding the kidney and mammary gland were isolated and weighed.

\section{Intake and Body Measurements}

Individual heifer BW, WH, hip height $(\mathbf{H H})$, heart girth (HG), and hip width (HW) measurements began at $3 \mathrm{~d}$ of age and were collected on the same day weekly until $90 \mathrm{~d}$ of age. From 90 to $320 \mathrm{~d}$ of age, BW and body skeletal measurements were taken every 2 wk. Thereafter, BW was determined every 2 wk and $\mathrm{WH}$, $\mathrm{HH}, \mathrm{HG}$, and HW measurements were taken monthly until calving. Body weight and skeletal measurements were also taken on d 3 postpartum.

The individual daily intakes of MR, WM, and starter mix were recorded until $90 \mathrm{~d}$ of age. Refusals of WM or 
MR were recorded from each meal, and the daily intake of the starter mix was also determined. From 150 to 320 d of age, DMI of each experimental group was recorded weekly during 2 consecutive days.

Age at puberty was determined by plasma progesterone concentrations in blood samples that were taken weekly from 120 to 320 d of age. Samples were collected via the jugular vein into heparinized vacuum tubes (Becton Dickinson, Franklin Lakes, NJ) and were immediately placed on ice. Plasma was separated from blood samples and stored at $-18^{\circ} \mathrm{C}$ pending analysis. Concentrations of progesterone in plasma were determined by RIA (Diagnostic Products, Los Angeles, CA). The intra- and interassay coefficients of variation for progesterone assay were 9.1 and $8.6 \%$, respectively. $\mathrm{Pu}-$ berty attainment was defined as the time when blood progesterone level reached $1 \mathrm{ng} / \mathrm{mL}$.

Heifers were first bred when they met the dual criteria of $340 \mathrm{~kg}$ of BW and $124 \mathrm{~cm}$ of WH, but not before 13 mo of age. After first calving, the cows were milked $3 \times$ daily and milk production was recorded electronically at each milking (SAE, Kibbutz Afikim, Israel). Milk samples were collected monthly from 3 consecutive milkings for fat, protein, and lactose determinations. Milk composition was determined by infrared analysis (standard IDF 141C; International Dairy Federation, 2000) at the laboratories of the Israeli Cattle Breeders Association.

\section{Statistical Analysis}

The body growth measurements and intake data until $60 \mathrm{~d}$ of age from both clusters were used for analysis, whereas only the first cluster of heifers was used for all other tests. The intake of liquid and starter mix was analyzed as repeated measurements using PROC MIXED of SAS (version 9.2; SAS Institute, 2002). The statistical model included nursery treatment, cluster, and age effects. The effect of cluster $\times$ treatment was tested and was not significant for any variable and therefore was excluded from the model.

Body weight and body skeletal measurements (WH, $\mathrm{HH}, \mathrm{HG}$, and HW) collected on individual heifers were fitted by regression analysis. Preliminary analysis, where data were fit to linear, quadratic, cubic, and quartic regression equations, showed that there was no improvement in fit with equations of a higher order than quadratic as determined by Mallows' Cp statistic and coefficient of determination. Therefore, quadratic regression equations fitted on individual animals over time were used to predict specific point in time growth measurements and the first derivatives of these equations were used to estimate growth rates at specific ages during the experiment (Moallem et al., 2004). Regression-predicted $\mathrm{BW}, \mathrm{WH}, \mathrm{HH}, \mathrm{HG}$, and $\mathrm{HW}$ and their corresponding direct growth rates from 60 to $650 \mathrm{~d}$ of age were analyzed using PROC MIXED of SAS (version 9.2; SAS Institute, 2002). The statistical model included effects of nursery treatment, prepubertal treatment, nursery treatment $\times$ prepubertal treatment (from $150 \mathrm{~d}$ of age), age, nursery treatment $\times$ age, prepubertal treatment $\times$ age, and nursery treatment $\times$ prepubertal treatment $\times$ age. Each variable was analyzed using the corresponding measurement at $3 \mathrm{~d}$ of age as a covariate. For analysis of data from 150 $\mathrm{d}$ and later, pen was used as replicate and heifer $\times$ treatment within pen was used as the random term to test treatment effects.

First-lactation milk and milk production were analyzed as repeated measurements using PROC MIXED of SAS (version 9.2; SAS institute, 2002) using the above model. The statistical model included nursery treatment, prepubertal protein treatment, nursery $\times$ prepubertal protein treatment, and DIM effects. The autoregressive order 1 was used as a covariance structure in the model.

Data of slaughtered animals were analyzed using the same model, with BW at $3 \mathrm{~d}$ of age used as a covariate in the analysis of covariance using PROC MIXED of SAS (version 9.2; SAS institute, 2002). The statistical model included effects of covariate, nursery treatment, and age.

Least squares means and adjusted SEM are presented in the tables. Unless otherwise stated, $P<0.05$ was accepted as statistically significant; tendencies were reported at $0.05<P<0.10$.

\section{RESULTS}

Calf performance through weaning is presented in Table 2. Average BW at weaning (60 d of age) was 3.1 $\mathrm{kg}$ higher $(P<0.01)$ and the ADG was $10 \%$ higher $(P$ $<0.01)$ in the WM heifers than in the MR heifers. No treatment differences were observed for other skeletal measurements at weaning. The MR calves consumed $0.12 \mathrm{~kg} / \mathrm{d}$ more DM than the WM heifers $(P<0.001)$, with the majority of the difference attributable to DM from MR. Calculated ME intake (Table 2) was not different between treatments, whereas the WM heifers consumed $0.019 \mathrm{~kg} / \mathrm{d}$ more $\mathrm{CP}(P<0.01)$ because of the higher $\mathrm{CP}$ content of $\mathrm{WM}$ as compared with MR (Table 2). Heifers fed WM had higher efficiency in exploitation of nutrients for BW gain (Table 2). Intake $(2.55 \mathrm{~kg} / \mathrm{d})$ and growth rates $(0.770 \mathrm{~kg} / \mathrm{d})$ from 60 to 90 $\mathrm{d}$ of age were not different among groups. The pattern of liquid and dry food intake and total DMI through 
Table 2. Body measurements at weaning; mean intake of milk, milk replacer, and starter mix; and feed efficiency calculations from birth to weaning at $60 \mathrm{~d}$ of age

\begin{tabular}{lllll}
\hline & \multicolumn{2}{c}{ Treatment $^{1}$} & & \\
\cline { 2 - 3 } Item & MR & WM & SEM & P-value $<$ \\
\hline Intake & & & & \\
Milk or MR, L/d & 9.78 & 8.97 & 0.09 & 0.001 \\
Milk or MR, kg of DM/d & 1.19 & 1.09 & 0.01 & 0.001 \\
Starter mix, kg/d & 0.17 & 0.18 & 0.017 & 0.62 \\
Total DMI, kg/d & 1.38 & 1.27 & 0.013 & 0.001 \\
ME, Mcal/d & 6.47 & 6.55 & 0.1 & 0.6 \\
Total CP, kg/d & 0.317 & 0.336 & 0.004 & 0.01 \\
DMI d 60-90, kg/d & 2.63 & 2.52 & 0.05 & 0.13 \\
Body measurements at weaning ${ }^{2}$ & & & & \\
BW, kg & 82.7 & 85.8 & 0.97 & 0.03 \\
WH, cm & 85.2 & 85.5 & 0.5 & 0.67 \\
HH, cm & 89.7 & 90.2 & 0.25 & 0.15 \\
HG, cm & 93.4 & 94.3 & 0.4 & 0.08 \\
HW, cm & 24.5 & 24.8 & 0.11 & 0.07 \\
Growth rate & & & & 0.01 \\
BW gain, kg & 41.0 & 45.1 & 1.14 & 0.01 \\
ADG, kg/d & 0.733 & 0.807 & 0.02 & 0.01 \\
Gain:feed efficiencies & & & & \\
BW/DM, kg/kg & 0.510 & 0.631 & 0.01 & 0.001 \\
BW/ME, kg/Mcal & 0.111 & 0.121 & 0.002 & 0.004 \\
BW/protein, kg/kg & 2.30 & 2.40 & 0.05 & 0.15 \\
\hline
\end{tabular}

${ }^{1}$ Heifer calves were fed until weaning either ad libitum milk replacer (MR) or whole milk (WM) that was offered for $30 \mathrm{~min}$ in 2 meals/d.

${ }^{2} \mathrm{WH}=$ withers height; $\mathrm{HH}=$ hip height; $\mathrm{HG}=$ heart girth; HW = hip width.

$80 \mathrm{~d}$ of age is presented in Figure 1 (panels A and B, respectively). Because of the high milk solids intake, the rate of increase in starter consumption through 50 $\mathrm{d}$ of age was slow. Once liquid supplementation was decreased (according to the experiment protocol), there was a steep increase in starter mix intake, with total DMI returning to d 50 intakes by 2 wk postweaning. The rate of increase in DMI (starter) after weaning tended to be higher in the MR group, where intake was $13.7 \%$ greater than in the WM group between 60 to 70 d of age $(P<0.08)$.

Growth measurements between 150 and $600 \mathrm{~d}$ of age are shown in Table 3. The DMI of the heifers that were fed the control diet during the prepuberty period was $6.6 \mathrm{~kg} / \mathrm{d}$ compared with $5.9 \mathrm{~kg} / \mathrm{d}$ in the heifers supplemented with $2 \%$ added protein. There were no effects of the $2 \%$ added protein or interaction between nursery treatments and protein supplementation. However, the $\mathrm{BW}$ of the WM heifers was 16.9 and $27.0 \mathrm{~kg}$ higher than that of the MR heifers at 300 and $600 \mathrm{~d}$ of age, respectively $(P<0.04)$, and $\mathrm{HH}$ and $\mathrm{HW}$ were also greater in the WM heifers until $450 \mathrm{~d}$ of age $(P<0.04)$. Growth rates are presented in Table 4 . The MR heifers had increased rates of $\mathrm{HH}$ and $\mathrm{HW}$ growth between 300 to $600 \mathrm{~d}$ of age $(P<0.04)$, and nursery treatment $\times$ age interaction was significant for $\mathrm{HH}$ and $\mathrm{HW}$ gain between 300 and $600 \mathrm{~d}$ of age $(P<0.005)$. The effect of age was significant for ADG of all measurements between 150 to $600 \mathrm{~d}$ of age $(P<0.0001)$. The interaction nursery treatment $\times$ prepubertal treatment $\times$ age for ADG of BW between 150 to $450 \mathrm{~d}$ of age was also significant $(P<0.02)$.

\section{Reproduction Performance}

Based on progesterone concentrations measured until $320 \mathrm{~d}$ of age, puberty was reached in only 10 out of 44 heifers. Of the heifers that showed puberty attainment, 8 heifers (out of $22 ; \sim 36 \%$ ) were from the WM group and 2 (out of $22 ; \sim 5 \%$ ) were from the MR group ( $P$ $<0.001$ ). Subsequent age at first AI was $24 \mathrm{~d}$ earlier (Table 5) in the WM heifers compared with the MR heifers $(P<0.05)$, with no effect of $2 \%$ added protein or nursery $\times$ protein interaction. Body weight at first AI was not different between nursery treatments and averaged $359 \mathrm{~kg}(P<0.72)$. The age at first pregnancy and age at calving were numerically lower (23 and 20 $\mathrm{d}$, respectively; $P>0.10$ ) in the WM group than in the MR group, with no effects of $2 \%$ added protein or interaction. The age at first calving was the lowest $(705$ d) for the WMC group and tended to be lower than the MRC group $(750 \mathrm{~d} ; P<0.07)$. At $3 \mathrm{~d}$ postpartum (Table 5), BW tended to be greater in the WM heifers (by $20.6 \mathrm{~kg} ; P<0.10$ ), with no effect of $2 \%$ added protein on body measurements at calving. The BW and 

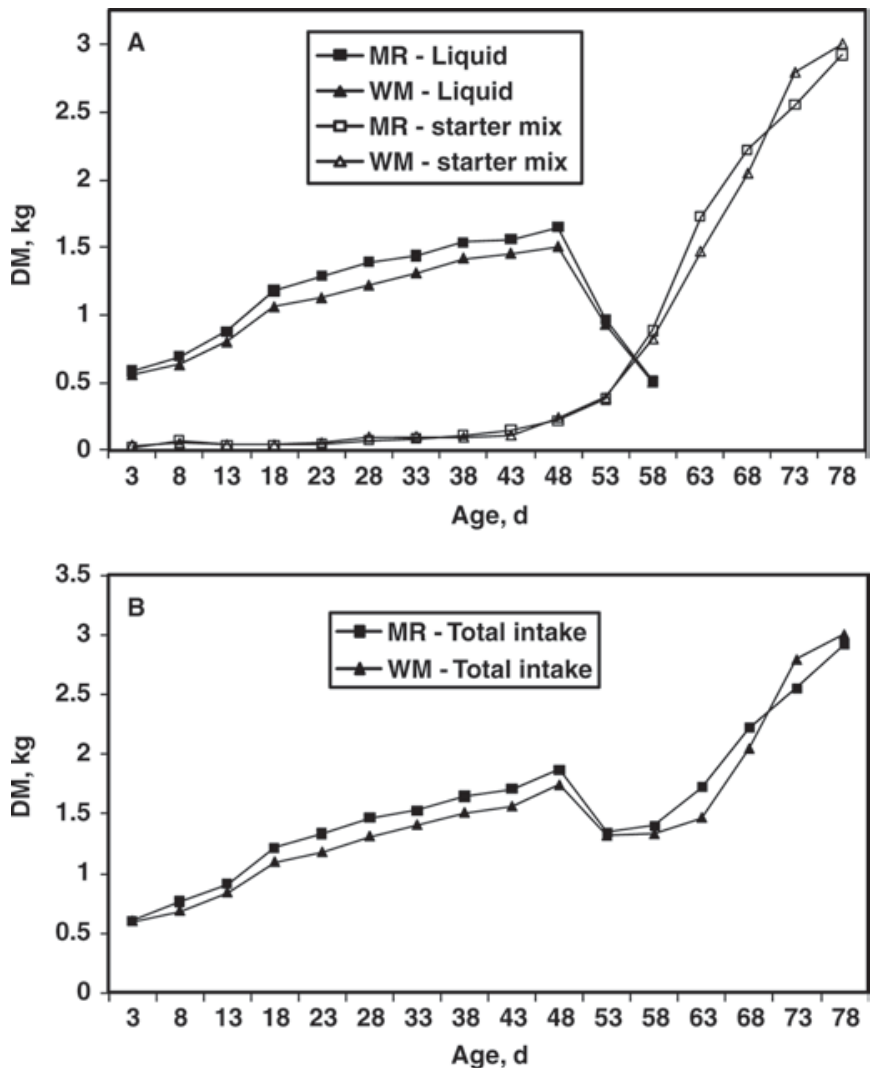

Figure 1. Least squares means of DMI of liquid food (whole milk or milk replacer) until $60 \mathrm{~d}$ of age in heifer calves fed either ad libitum milk replacer (MR; $\mathbf{\square})$ or whole milk (WM; $\mathbf{\Delta})$, and starter mix intake until $80 \mathrm{~d}$ of age of the MR $(\square)$ or WM $(\Delta)$ heifers (panel A). The least squares means in panel $\mathrm{B}$ show the total intake (liquid and starter mix) for the MR (ם) or WM ( $\mathbf{\Delta})$ heifers until $80 \mathrm{~d}$ of age. The SEM for liquid food and starter mix in panel A was 0.001 and 0.02 , respectively, and the SEM for total intake in panel B was 0.02 .

HW at calving of the WMP heifers were higher than that of the MRP heifers $(P<0.04)$.

\section{First-Lactation Performance}

Thirty-six heifers $(10,8,8$, and 10 for MRC, MRP, WMC, and WMP, respectively) completed first lactation. Milk production during the first $305 \mathrm{~d}$ postpartum was $3.1 \mathrm{~kg}(10.2 \%)$ higher in the WM group compared with the MR group $(P<0.001$; Table 5). Added protein during the prepubertal period tended to increase milk production $(P<0.08)$. Also, there was a positive interaction between the nursery treatments and prepubertal added protein on milk yield, where milk production of the WMP group was $12.4 \%$ higher than in all other groups $(P<0.001)$. There were no main effects of nursery treatment or $2 \%$ added protein on fat percentage, but a significant interaction was found $(P<0.05)$ in which fat percentage in the WMP group was lower than in all other groups. This may have been related to higher milk yield in this group. Milk fat yield $(\mathrm{kg} / \mathrm{d})$ was $7.5 \%$ higher in the WM group than in the MR group $(P<0.001)$, whereas no effects of $2 \%$ added protein were observed. Milk protein percentage was lower in the WM group than in the MR group, whereas no effect of the $2 \%$ added protein was observed. There was a significant interaction $(P<0.001)$ between nursery treatments and $2 \%$ added protein on milk protein content in milk, where protein percentage in the WMP group was lower than in other groups. Milk protein yield $(\mathrm{kg} / \mathrm{d})$ was higher in the WM group than in the MR group $(P<0.001)$, with no interaction. The $4 \%$ FCM was $7.1 \%$ higher in the WM group than in the MR group. As for milk yield, a positive interaction between nursery milk and $2 \%$ added protein was observed for FCM, which was the highest in the WMP group and the lowest in the MRP group.

\section{Slaughtered Heifers Data}

Body component weights and weights expressed as a percentage of empty body weight (EBW) at weaning are shown in Table 6. Omasum and abomasum weights were higher in the WM calves than in the MR calves $(P$ $<0.05$ ), and small intestine weight tended to be higher in that group $(P<0.09)$. The omental weight was 2.8 fold higher in the WM heifers than in the MR heifers, and the total digestive tract weight was $23 \%$ higher in the WM group than in the MR group $(P<0.09)$. Heart weight tended to be higher $(P<0.07)$, whereas the weights of the liver, lungs, and kidney were numerically higher in the WM heifers than the MR heifers. Mesentery fat weight was $60 \%$ higher $(P<0.02)$ and the weight of the kidney fat was 2.3-fold higher $(P<$ 0.04) in the WM heifers than in the MR heifers. The weight of the mammary gland fat pad tended to be greater in the WM heifers than in the MR heifers $(P<$ 0.09 ), and the total fat mass (mesentery, kidney, groin, and mammary) was $78 \%$ higher in the WM heifers than in the MR heifers $(P<0.02)$.

The weights of the digestive tract components as a percentage of EBW were numerically but not significantly higher in the WM heifers $(P<0.38)$. The omental weight as a percentage of EBW was 2.6-fold higher in the WM heifers than in the MR heifers $(P<0.004)$. The mesentery fat expressed as a percentage of EBW was higher in the WM heifers than in the MR heifers $(P<0.007)$, whereas the kidney and mammary gland fat pad weights tended to be higher in the WM heifers than in the MR heifers $(P<0.07)$. Overall fat mass, expressed as a percentage of EBW, was also higher in the WM heifers than in the MR heifers $(P<0.02)$.

At 10 mo of age, the kidney weight was higher in the WM heifers than in the MR heifers $(0.91$ and $0.85 \mathrm{~kg}$, 
Table 3. Least squares means for body measurements from 150 to $600 \mathrm{~d}$ of age

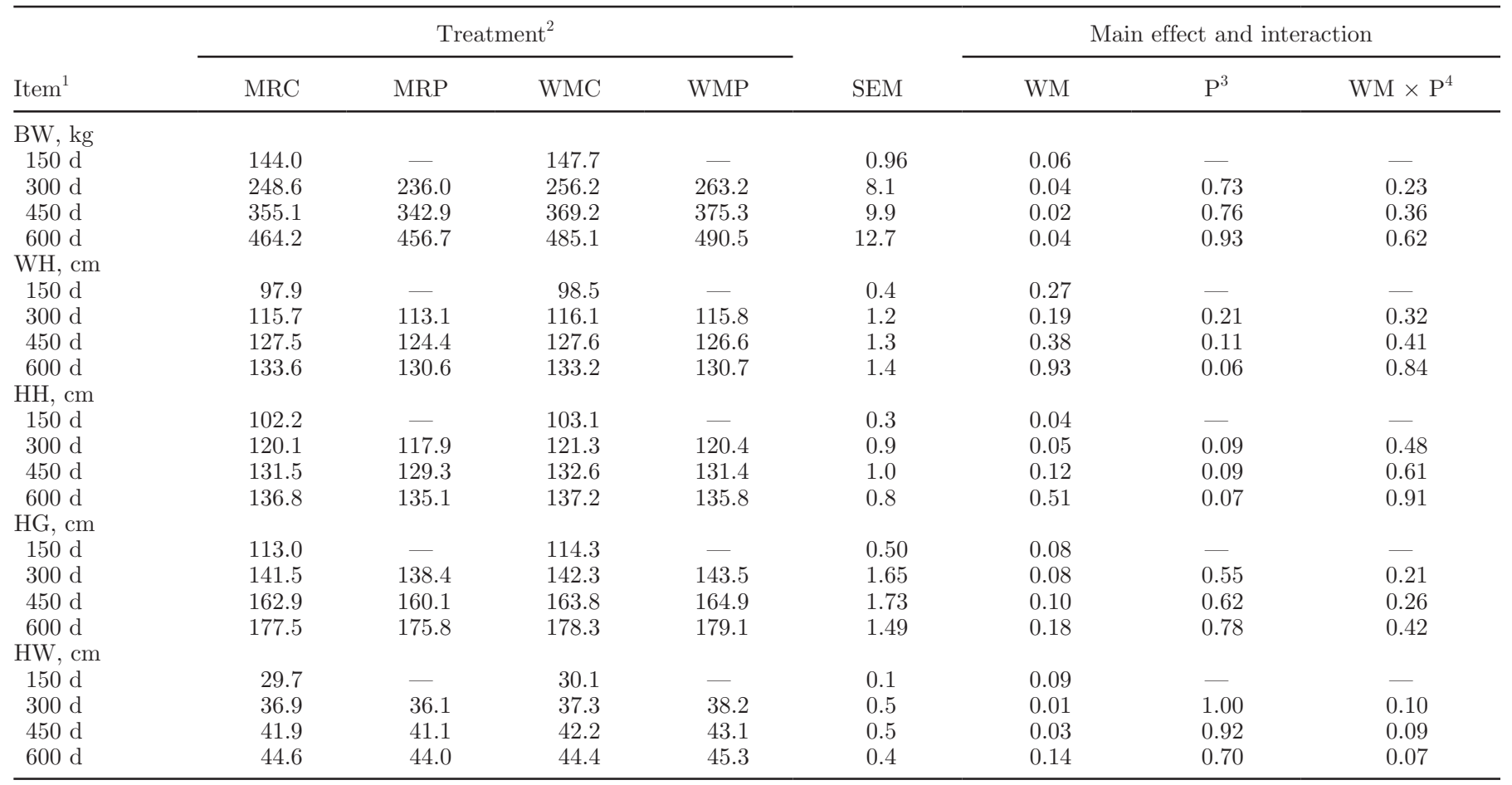

${ }^{1} \mathrm{WH}=$ withers height; $\mathrm{HH}=$ hip height; $\mathrm{HG}=$ heart girth; HW = hip width.

${ }^{2}$ Heifer calves were fed until weaning either ad libitum milk replacer (MR) or whole milk (WM) that was offered for 30 min twice daily. The heifers were fed the same ration from 60 to $150 \mathrm{~d}$ of age. At $150 \mathrm{~d}$ of age, each original group was divided into 2 subgroups and fed either the control diet (C) or a diet supplemented with $2 \%$ protein $(\mathrm{P})$ until $320 \mathrm{~d}$ of age. From $320 \mathrm{~d}$ of age, all the heifers were housed and fed together until calving.

${ }^{3}$ Effect of $2 \%$ added protein during the prepubertal period.

${ }^{4}$ The interaction between preweaning milk treatment and prepubertal dietary protein.

respectively; $P<0.01$ ), whereas the kidney fat weight was numerically higher, with no differences in the mammary fat pad weight between groups (1.71 and $1.79 \mathrm{~kg}$ for MR and WM heifers, respectively).

\section{DISCUSSION}

We previously demonstrated that heifer calves fed ad libitum WM during the nursery period dramatically increased BW and other skeletal measurements at weaning when compared with calves fed a standard MR regimen (Shamay et al., 2005). In the current study in which calves were offered similar amounts of liquid (WM or MR), the differences between groups at weaning were much smaller (3.1 kg of BW difference as compared with $14.5 \mathrm{~kg}$; Shamay et al., 2005), with no differences in other skeletal measurements (WH, HH, $\mathrm{HG}$, and HW). Slaughter data in the current study and in a previous study (data not published) revealed that the MR heifers gained less fat than the WM heifers. Moreover, the lack of differences in skeletal growth and the differences in BW suggest greater fat deposition in the WM heifers, resulting in increased $\mathrm{BW}$ in the WM calves at weaning. Although the concentrations of ME and protein in the WM were higher than those of the MR, the MR heifers consumed similar amounts of ME and only slightly lower amounts of protein than the WM calves $(0.019 \mathrm{~kg} / \mathrm{d})$, with no indication of fattening. These results are in accordance with other reports that have demonstrated the potential of MR fed in high feeding rates to increase ADG during the nursery period, without increasing fat deposition (Diaz et al., 2001; Blome et al., 2003; Brown et al., 2005a). Increased feeding rates of MR along with higher protein concentrations were also shown to decrease fat deposition and increase lean body growth (Bartlett et al., 2006). In contrast to increased MR feeding, high feeding rates of WM in the current study and our previous study resulted in increasing fat deposition.

Although in both groups the liquid food was reduced gradually during the last $10 \mathrm{~d}$, both groups exhibited a dramatic decrease in total DMI at $50 \mathrm{~d}$ of age, demonstrating a typical decrease during the transition from liquid to dry food, as was also observed in Quigley et 
Table 4. Average rate of gain of body measurements from 60 to $600 \mathrm{~d}$ of age

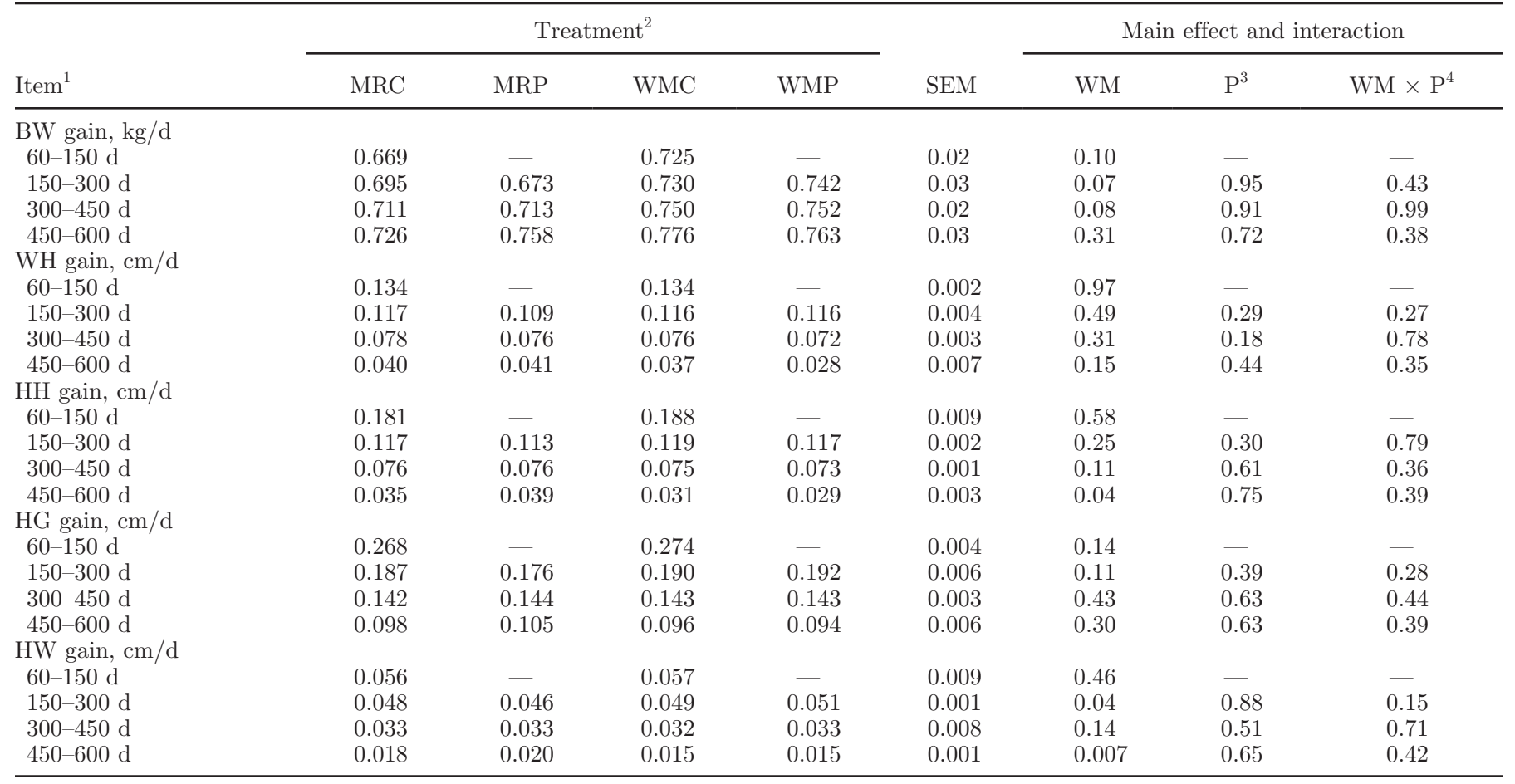

${ }^{1} \mathrm{WH}=$ withers height; $\mathrm{HH}=$ hip height; $\mathrm{HG}=$ heart girth; HW = hip width.

${ }^{2}$ Heifer calves were fed until weaning either ad libitum milk replacer (MR) or whole milk (WM) that was offered for 30 min twice daily. The heifers were fed the same ration from 60 to $150 \mathrm{~d}$ of age. At $150 \mathrm{~d}$ of age, each original group was divided into 2 subgroups and fed either the control diet (C) or a diet supplemented with $2 \%$ protein $(\mathrm{P})$ until $320 \mathrm{~d}$ of age. From $320 \mathrm{~d}$ of age, all the heifers were housed and fed together until calving.

${ }^{3}$ Effect of $2 \%$ added protein during the prepubertal period.

${ }^{4}$ The interaction between preweaning milk treatment and prepubertal dietary protein.

al. (2006). The calves in both groups were offered ad libitum amounts of liquid and therefore their starter mix intake was relatively low, which might influence the development of the ruminant components of the digestive tract. Similar results were observed in Jasper and Weary (2002), in which heifers that were fed ad libitum milk consumed lesser amounts of dry food during the nursery period. In our previous study, 8 heifers were slaughtered at weaning and the rumen, reticulum, omasum, and abomasum weights as a percentage of EBW were 1.5-fold higher in calves that were fed standard regimen of MR as compared with ad libitum WM (data not published; 3.84 and 2.54\%, respectively; $P<0.006$ ). However, in the current study in which both groups were offered similar amounts of liquid food, differences in the reticular rumen, omasal and abomasal weights were small (2.35 vs. $2.05 \% ; P>$ 0.45 ) and averaged only $57 \%$ of that of control calves in the previous study (Shamay et al., 2005). Perhaps this was because starter mix intake was 3 -fold greater $(0.65$ vs. $0.20 \mathrm{~kg} / \mathrm{d})$ in heifers fed standard amounts of MR in the previous study (Shamay et al., 2005).
Collectively, these data underline the importance of dry food consumption during the nursery period to encourage rumen and digestive tract development in the calf, thereby reducing the typical effect of transition from liquid to dry food on feed DMI at weaning.

Effects of added protein during the prepubertal period on heifer growth are inconsistent. In the current study and in Whitlock et al. (2002), no effects of added protein on ADG or skeletal development were observed. However, other studies showed enhanced growth rates with increasing MP in the diet (Pirlo et al., 1997; Moallem et al., 2004; Shamay et al., 2005). In the present study, DMI during the prepubertal period in the group fed $2 \%$ added protein was lower than that of controls, similar to the response reported by Shamay et al. (2005), but not by Moallem et al. (2004). Casper et al. (1994) observed increased ADG in heifers fed added RUP rather than RDP, and the higher growth rate that was observed in Moallem et al. (2004) and Shamay et al. (2005) might be attributable to the source of the supplemented protein (fish meal), which contains a high proportion of RUP. The inconsistency 
Table 5. Reproductive performance, body measurements at calving, and milk and milk solids yield during the first lactation

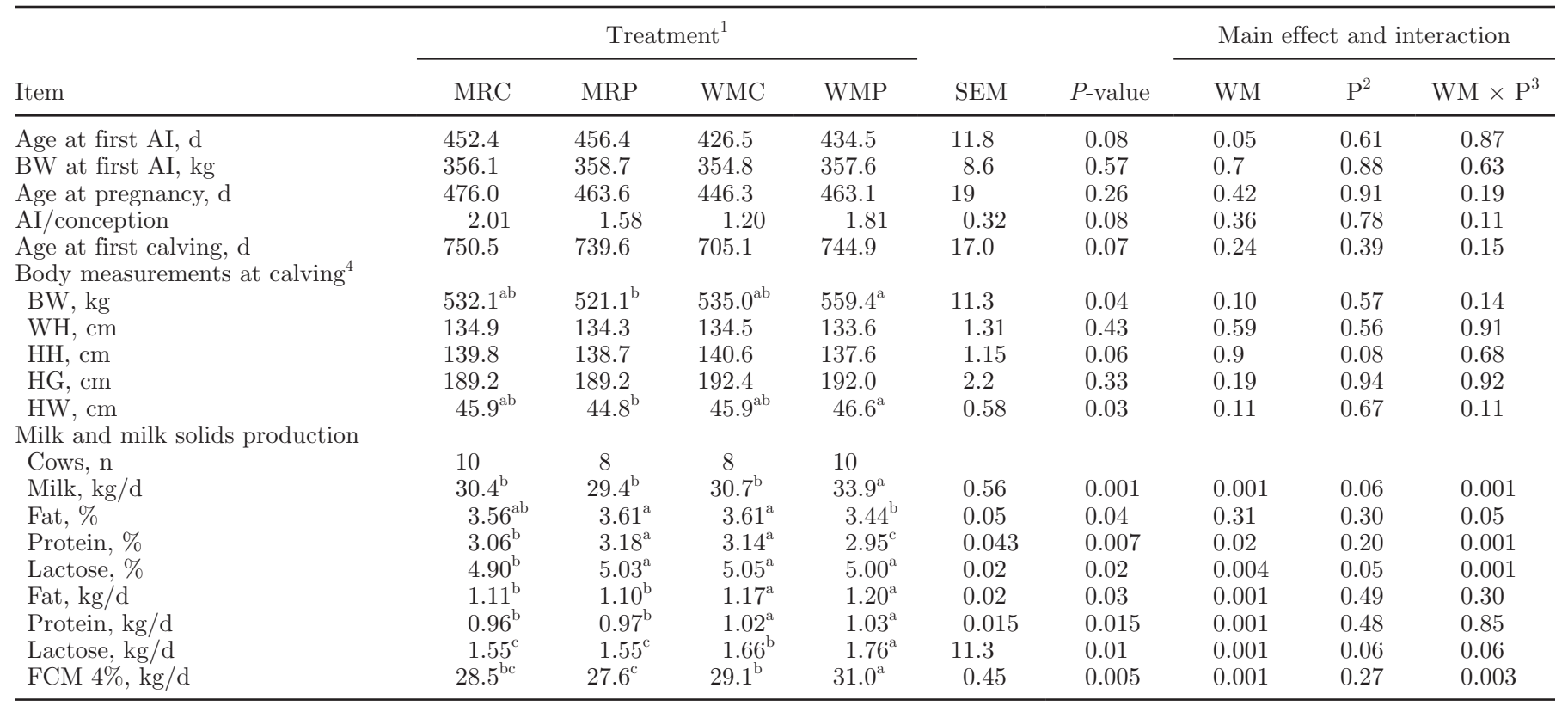

${ }^{\mathrm{a}-\mathrm{c}}$ Means within a row with different superscripts differ $(P<0.05)$.

${ }^{1}$ Heifer calves were fed until weaning either ad libitum milk replacer (MR) or whole milk (WM) that was offered for 30 min twice daily. The heifers were fed the same ration from 60 to $150 \mathrm{~d}$ of age. At $150 \mathrm{~d}$ of age, each original group was divided into 2 subgroups and fed either the control diet (C) or a diet supplemented with $2 \%$ protein $(\mathrm{P})$ until $320 \mathrm{~d}$ of age. From $320 \mathrm{~d}$ of age, all the heifers were housed and fed together until calving.

${ }^{2}$ Effect of $2 \%$ added protein during the prepubertal period.

${ }^{3}$ The interaction between preweaning milk treatment and prepubertal dietary protein.

${ }^{4} \mathrm{WH}=$ withers height; $\mathrm{HH}=$ hip height; $\mathrm{HG}=$ heart girth; HW = hip width.

in the effects of added protein on prepubertal growth rates might also be ascribed to the diversity of energy sources in the heifer's rations, as was also observed in Casper et al. (1994).

Differences in BW between both groups were evident during the entire rearing period where WM heifers were 6 to $7 \%$ heavier than MR heifers. However, ADG did not differ between groups during the postweaning period, and the advantage in BW that was achieved at weaning persisted until calving. The same pattern of growth was also demonstrated in Shamay et al. (2005), in which differences in BW at weaning persisted later during the rearing period. Little and Kay (1979) and Macdonald et al. (2005) reported long-term effect of accelerated growth rate during the prepuberty period on BW at the subsequent lactation. In another study, Barash et al. (1994) demonstrated a similar pattern, where Holstein bulls that were assigned to restricted nutrition followed by realimentation period failed to reach the BW of bulls fed conventional management. In contrast to $\mathrm{BW}, \mathrm{HH}$ and $\mathrm{HW}$ were higher in the WM heifers than in the MR heifers during the prepubertal period. But from 450 to $600 \mathrm{~d}$ of age, $\mathrm{HW}$ and $\mathrm{HH}$ growth rates were greater in the MR heifers than in the WM heifers, resulting in similar $\mathrm{HW}$ and $\mathrm{HH}$ at $600 \mathrm{~d}$ of age, as was also reflected by significant interaction between nursery treatment and age. The same pattern was observed in Shamay et al. (2005), which indicated compensation in skeletal growth but not in body mass during the late rearing period that might be associated with the genetic potential of the heifers. These findings imply different mechanism in the pattern of skeletal growth as compared with BW, in which differences that could be achieved at weaning in BW might persist for a longer period whereas skeletal measurement advantages may disappear with time of rearing period.

Heifers fed WM averaged $10 \%$ more milk and $7 \%$ more FCM than the heifers fed MR during the first lactation, whereas the WMP heifers produced on average $12 \%$ more milk and 9\% more FCM compared with other groups. These finding are in accordance with Shamay et al. (2005), in which heifers fed WM and supplemented dietary protein during the prepubertal period produced the highest milk yields. The growth rate of all the heifers during the prepubertal age was 0.700 to $0.747 \mathrm{~kg} / \mathrm{d}$, with slight advantage to the WM 
Table 6. Body component weights $(\mathrm{kg})$ and amounts expressed as a percentage of empty body weight (EBW) of Holstein heifers slaughtered at 2 mo of age

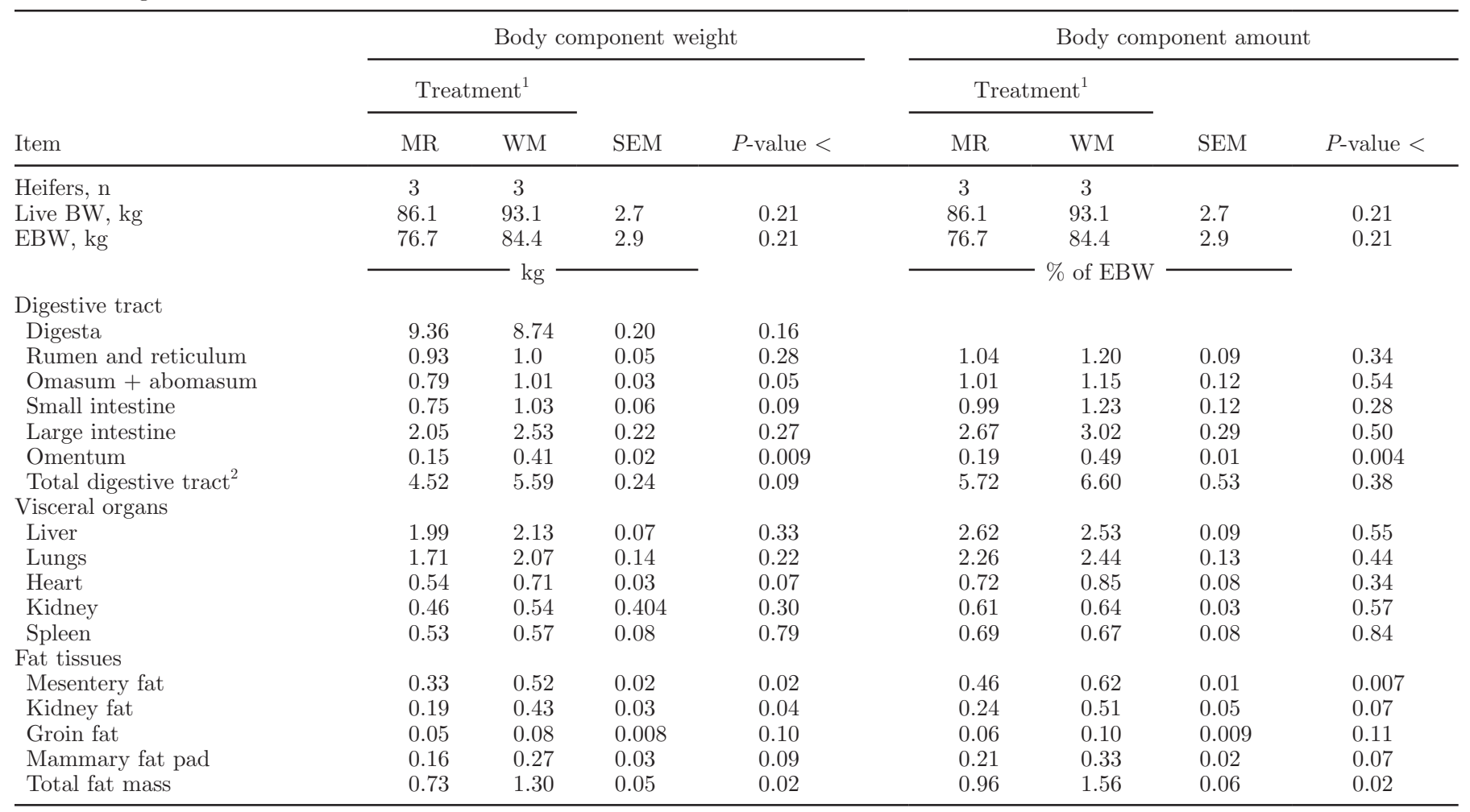

${ }^{1}$ Heifer calves were fed until weaning either ad libitum milk replacer (MR) or whole milk (WM) that was offered for 30 min in 2 meals/d.

${ }^{2}$ Without digesta.

heifers. These growth rates were within the range found by Zanton and Heinrichs (2005) to be optimal for milk production.

Hoffman and Funk (1992) found a positive relationship between BW at calving and first-lactation milk yield. In the current study, using data for all treatments, BW ( $\mathrm{r}=0.37 ; P<0.03)$, HW $(\mathrm{r}=0.48 ; P<$ $0.004)$, and HG $(\mathrm{r}=0.35 ; P<0.05)$ at calving were all positively related to first-lactation milk production but not to WH and HH. Sejrsen et al. (2002) proposed that the positive correlation between $\mathrm{BW}$ and milk production is mainly attributable to a positive relationship between growth rate capacity, which is related to the genetic potential, and milk yield. Heifers that are selected for high milk yield have a higher growth capacity and calve with higher BW. However, in the current study, the difference in BW at calving was obtained by nutritional management rather than by genetic potential, and yet there was still a positive relationship between BW at calving and milk production.

The effects of nursery milk on growth rate from weaning until calving were relatively small, where BW and HW, but not other skeletal measurements, tended to be higher at calving in the WM group. However, the WM heifers produced more milk than the MR heifers, which leads to the conclusion that high growth rate during the nursery period as a result of ad libitum WM regimen had positive long-term effect on milk production. Several experiments have found that increasing the prepubertal ADG decreases milk production because of detrimental effects on mammary gland development (Lammers et al., 1999; Radcliff et al., 2000), whereas other studies did not observe such an association (Abeni et al., 2000; Carson et al., 2000). In the current study, the prominent effects of the nursery milk on growth rate were until weaning, whereas afterward the differences in growth rate were minor. An earlier study showed that the mammary growth before puberty was unaffected by feeding level during the nursery period (Sejrsen et al., 1998). More recently, Brown et al. (2005b) showed that feeding MR with high protein and energy concentrations at high feeding rates increased extraparenchymal fat but also enhanced mammary parenchymal mass, DNA, and RNA. Collectively, it might be concluded that the detrimental effects of accelerated growth rates are related to the prepubertal allometric growth phase of mammary development but not to the isometric growth phase during the nursery period. 
Slaughter data in the current study indicated higher fat deposition in the WM heifers than in the MR heifers. The mammary fat pad is believed to be a hormone-producing tissue (Walden et al., 1998; Meyer et al., 2006) and it was suggested that the adipocyte-epithelial cell interaction is critical for mammary duct growth and morphogenesis (Hovey et al., 1999). In respect to the emerging evidence on the interaction between fat pad and mammary gland development (Meyer et al., 2006; Feuermann et al., 2009), we believe that the greater fat mass in the WM heifers may contribute in a paracrine and endocrine manner to mammary gland development at an early age, which was subsequently reflected by long-term effects on milk production. Using results of the present study, one might speculate that the ad libitum milk supply (rather than effects on growth rate or effect of fat pad) plays a positive role in enhancing future production.

\section{CONCLUSIONS}

Feeding calves ad libitum WM versus MR increased BW at weaning, primarily by increasing body fat deposition, while having no effects on other skeletal measurements. Nursery management and $2 \%$ added protein had small effects on growth rates after weaning, but the differences in BW at weaning were evident throughout the entire rearing period. The WM heifers produced more milk during the first lactation than the MR heifers, with positive interaction between nursery milk and prepuberty $2 \%$ added protein. Preweaning WM at high feeding rates appears to have long-term effects that are beneficial to future milk production. The enhanced milk production of the heifers nursed with WM may be related to the ad libitum whole milk supply, paracrine or endocrine effects of fat tissues, or an interaction between both.

\section{ACKNOWLEDGMENTS}

We gratefully thank the team of the experimental dairy farm at the Volcani Center (Bet Dagan, Israel) for their assistance with animal care.

\section{REFERENCES}

Abeni, F., L. Calamari, L. Stefanini, and G. Pirlo. 2000. Effects of daily gain in pre-and postpubertal replacement dairy heifers on body condition score, body size, metabolic profile, and future milk production. J. Dairy Sci. 83:1468-1478.

Bar-Peled, U., B. Robinzon, E. Maltz, H. Tagari, Y. Folman, I. Bruckental, H. Voet, H. Gacitua, and A. R. Lehrer. 1997. Increased weight gain and effects on production parameters on Holstein heifer calves that were allowed to suckle from birth to six weeks of age. J. Dairy Sci. 80:2523-2528.

Barash, H., Y. Bar-Meir, and I. Bruckental. 1994. Effects of a low energy diet followed by a compensatory diet on growth, puberty and milk production in dairy heifers. Livest. Prod. Sci. 39:263268.

Bartlett, K. S., F. K. McKeith, M. J. VandeHaar, G. E. Dahl, and J. K. Drackley. 2006. Growth and body composition of dairy calves fed milk replacers containing different amounts of protein at two feeding rates. J. Anim. Sci. 84:1454-1467.

Blome, R. M., J. K. Drackley, F. K. McKeith, M. F. Hutjens, and G. C. McCoy. 2003. Growth, nutrient utilization, and body composition of dairy calves fed milk replacers containing different amounts of protein. J. Anim. Sci. 81:1641-1655.

Brown, E. G., M. J. VandeHaar, K. M. Daniels, J. S. Liesman, L. T. Chapin, J. W. Forrest, R. M. Akers, R. E. Pearson, and M. S. Weber Nielsen. 2005b. Effect of increasing energy and protein intake on mammary development in heifer calves. J. Dairy Sci. $88: 595-603$.

Brown, E. G., M. J. VandeHaar, K. M. Daniels, J. S. Liesman, L. T. Chapin, D. H. Keisler, and M. S. Weber Nielsen. 2005a. Effect of increasing energy and protein intake on body growth and carcass composition of heifer calves. J. Dairy Sci. 88:585-594.

Capuco, A. V., J. J. Smith, D. R. Waldo, and C. E. Rexroad Jr. 1995. Influence of prepubertal dietary regimen on mammary growth of Holstein heifers. J. Dairy Sci. 78:2709-2725.

Carson, A. F., A. R. C. Wylie, J. D. G. McEvoy, M. McCoy, and L. E. R. Dawson. 2000. The effects of plane of nutrition and diet type on metabolic hormone concentrations, growth and milk production in high genetic merit dairy replacement heifers. Anim. Sci. 70:349 362 .

Casper, D. P., D. J. Schingoethe, M. J. Brouk, and H. A. Maiga. 1994. Nonstructural carbohydrate and undegradable protein sources in the diet: Growth responses of dairy heifers. J. Dairy Sci. 77:25952604.

Diaz, M. C., M. E. Van Amburgh, J. M. Smith, J. M. Kelsey, and E. L. Hutten. 2001. Composition of growth of Holstein calves fed milk replacer from birth to 105- kilogram body weight. J. Dairy Sci. 84:830-842.

Feuermann, Y., S. J. Mabjeesh, and A. Shamay. 2009. Mammary fat can adjust prolactin effect on mammary epithelial cells via leptin and estrogen. Int. J. Endocrinol. doi:10.1155/2009/427260

Foldager, J., and K. Sejrsen. 1991. Rearing intensity in dairy heifers and the effect on subsequent milk production. [In Danish with English summary and subtitles.] Report 693. Natl. Inst. Anim. Sci., Foulum, Denmark.

Hoffman, P. C., and D. A. Funk. 1992. Applied dynamics of dairy replacement growth and management. J. Dairy Sci. 75:25042516.

Hovey, R. C., T. B. McFadden, and R. M. Akers. 1999. Regulation of mammary gland growth and morphogenesis by the mammary fat pad: A species comparison. J. Mammary Gland Biol. Neoplasia $4: 53-68$.

International Dairy Federation. 2000. IDF Standard 141c:2000: Determination of milk fat, protein and lactose content guidance on the operation of mid-infrared instruments. International Dairy Federation, Brussels, Belgium.

Jasper, J., and D. M. Weary. 2002. Effects of ad libitum milk intake on dairy calves. J. Dairy Sci. 85:3054-3058.

Lammers, B. P., A. J. Heinrichs, and R. S. Kensinger. 1999. The effects of accelerated growth rates and estrogen implants in prepubertal Holstein heifers on estimates of mammary development and subsequent reproduction and milk production. J. Dairy Sci. 82:1753-1764.

Little, W., and R. M. Kay. 1979. The effects of rapid rearing and early calving on the subsequent performance of dairy heifers. Anim. Prod. 29:131-142.

Macdonald, K. A., J. W. Penno, A. M. Bryant, and J. R. Roche. 2005. Effect of feeding level pre- and post-puberty and body weight at first calving on growth, milk production, and fertility in grazing dairy cows. J. Dairy Sci. 88:3363-3375.

Meyer, M. J., A. V. Capuco, Y. R. Boisclair, and M. E. Van Amburgh. 2006. Estrogen-dependent responses of the mammary fat pad in prepubertal dairy heifers. J. Endocrinol. 190:819-827. 
Moallem, U., G. E. Dahl, E. K. Duffey, A. V. Capuco, and R. A. Erdman. 2004. Bovine somatotropin and rumen-undegradable protein effects on skeletal growth in prepubertal dairy heifers. J. Dairy Sci. 87:3881-3888.

National Research Council. 2001. Nutrient Requirements of Dairy Cattle. 7th rev. ed. National Academy of Science, Washington, DC.

Pirlo, G., M. Capelletti, and G. Marchetto. 1997. Effects of energy and protein allowances in the diets of prepubertal heifers on growth and milk production. J. Dairy Sci. 80:730-739.

Quigley, J. D., T. A. Wolfe, and T. H. Elsasser. 2006. Effects of additional milk replacer feeding on calf health, growth, and selected blood metabolites in calves. J. Dairy Sci. 89:207-216.

Radcliff, R. P., M. J. Vandehaar, A. L. Skidmore, L. T. Chapin, B. R. Radke, J. W. Lloyd, E. P. Stanisiewski, and H. A. Tucker. 2000 Effects of diet and injection of bovine somatotropin on prepubertal growth and first-lactation milk yields of Holstein cows. J. Dairy Sci. 83:23-29.

SAS Institute. 2002. SAS User's Guide: Statistics. Version 9.2. SAS Inst. Inc., Cary, NC.

Sejrsen, K., J. T. Huber, H. A. Tucker, and R. M. Akers. 1982. Influence of nutrition on mammary development in pre- and postpubertal heifers. J. Dairy Sci. 65:793-800.

Sejrsen, K., S. Purup, S. H. Martinussen, and M. Vestergaard. 1998 Effect of feeding level in calves and prepubertal heifers. J. Dairy Sci. 81(Suppl. 1):377 (Abstr.)

Sejrsen, K., S. Purup, M. Vestergaard, and J. Foldager. 2002. High body weight gain and reduced bovine mammary growth: Physiological basis and implications for milk yield potential. Domest. Anim. Endocrinol. 19:93-104.

Shamay, A., D. Werner, U. Moallem, H. Barash, and I. Bruckental. 2005. Effect of nursing management and skeletal size at weaning on puberty, skeletal growth rate, and milk production during first lactation of dairy heifers. J. Dairy Sci. 88:1460-1469.

Silva, L. F. P., M. J. VandeHaar, B. K. Whitlock, R. P. Radcliff, and H. A. Tucker. 2002. Short communication: Relationship between body growth and mammary development in dairy heifers. J. Dairy Sci. 85:2600-2602

Sinha, Y. N., and H. A. Tucker. 1969. Mammary development and pituitary prolactin level of heifers from birth through puberty and during the estrous cycle. J. Dairy Sci. 52:507-512.

Swanson, E. W., and G. I. Poffenbarger. 1977. Mammary gland development of dairy heifers during their first gestation. J. Dairy Sci. 62:702-714

Walden, P. D., W. Ruan, M. Feldman, and D. L. Kleinberg. 1998. Evidence that the mammary fat pad mediates the action of growth hormone in mammary gland development. Endocrinology 139:659-662.

Whitlock, B. K., M. J. VandeHaar, L. F. P. Silva, and H. A. Tucker. 2002. Effect of dietary protein on prepubertal mammary development in rapidly growing dairy heifers. J. Dairy Sci. 85:1516-1525.

Zanton, G. I., and A. J. Heinrichs. 2005. Meta-analysis to assess effect of prepubertal average daily gain of Holstein heifers on firstlactation production. J. Dairy Sci. 88:3860-3867. 